\title{
Converging on euroscepticism
}

\section{Online polity contestation during European Parliament elections}

Trenz, Hans-Jörg; de Wilde, Pieter; Michailidou, Asimina

Published in:

European Journal of Political Research

DOI:

$10.1111 / 1475-6765.12050$

Publication date:

2014

Document version

Early version, also known as pre-print

Citation for published version (APA):

Trenz, H-J., de Wilde, P., \& Michailidou, A. (2014). Converging on euroscepticism: Online polity contestation during European Parliament elections. European Journal of Political Research, Vol. 53(no. 4), 766-783.

https://doi.org/10.1111/1475-6765.12050 


\title{
Converging on euroscepticism: Online polity contestation during European Parliament elections
}

\author{
PIETER DE WILDE, ${ }^{1}$ ASIMINA MICHAILIDOU ${ }^{2} \&$ HANS-JÖRG TRENZ ${ }^{2,3}$ \\ ${ }^{1}$ WZB Berlin Social Science Centre, Germany; ${ }^{2}$ Centre for European Studies (ARENA), Oslo, Norway; \\ ${ }^{3}$ Centre for Modern European Studies (CEMES), Copenhagen, Denmark
}

\begin{abstract}
Does the increasing politicisation of Europe signify a step towards the legitimation of the Union? This could be the case if the increased public intensity of debate and polarisation of opinion brought about by politicisation do not fragment the audience and if arguments presented in public are sufficiently clear about the desired nature of the polity. To answer this question, the focus of this article is on dynamic contestation in the public sphere using original data of news platforms and political blogs in 12 EU Member States and transnational websites during the European Parliament election campaign of 2009. The results are, first, that diffuse eurosceptic evaluations dominate public debates despite large variation in the intensity of debate across Member States. Second, a majority of evaluations made, particularly those by citizens leaving comments online, are negative in all countries included in this study. A gap between elites and citizens persists, but it appears less pronounced than often proclaimed in the literature. And third, democracy is a primary concern in EU polity contestation, especially for those evaluating the EU negatively. Although little evidence is found of a fragmentation of audiences, the prominence of diffuse euroscepticism poses a major challenge to legitimation of the Union.
\end{abstract}

Keywords: democratic legitimacy; European Union; euroscepticism; online media; politicisation

\section{Introduction}

Political contestation has placed the problem of the legitimacy of the European Union (EU) in a new light. It is now widely debated in the broader public sphere of every Member State whether the EU is legitimate (Boomgaarden et al. 2013; Koopmans \& Statham 2010; Risse 2010). Decisions in EU framework are closely scrutinised and questioned by the media (e.g., Boomgaarden et al. 2013), the public and national parliaments (e.g., Winzen 2012). Hence, EU issues have profound impact on politics at the national and EU levels. Political conflicts concerning European integration have intensified and mobilised a wide range of actors including political parties, social movements, interest groups and citizens (Hooghe \& Marks 2009; Statham \& Trenz 2013). This process of 'politicisation' (De Wilde 2011) entails a polarisation of opinions and viewpoints. As different ideas and opinions meet in public debate, the audience is exposed to the various arguments and could potentially be persuaded in various directions. While politicisation thus features disagreement, it could simultaneously signify a process towards reaching a new (or old) consensus. As long as audiences are not fragmented to the point of being exposed to like-minded people only (Dahlgren 2009) and arguments about European integration and the EU are made with sufficient clarity about what exactly is demanded and why (Morgan 2005), politicisation can function as a process supporting the legitimation rather than delegitimation of the EU polity (Rauh \& Zürn 2013). 
To assess politicisation's potential for legitimation, we proceed to map the extent to which publics are exposed to various arguments and the extent to which such arguments are sufficiently complete concerning what is demanded and why. Based on original data from online media platforms in 12 EU Member States during the 2009 European Parliament (EP) elections, we show that publics are sufficiently interconnected as each Member State features similar plurality in articulated opinions, but that the most prominent line of argument is not clear enough about what the EU should look like. Although it is clear that the makers of such arguments are dissatisfied with the EU, it remains unclear what would alleviate this dissatisfaction. This form of 'diffuse euroscepticism' is widespread and presents a serious challenge to the legitimation of the EU.

\section{EU polity contestation in the public sphere}

Research on the politicisation of European integration (De Wilde 2011; De Wilde \& Zürn 2012; Hooghe \& Marks 2009; Rauh 2012; Statham \& Trenz 2013) draws our attention to the process and status of increasing societal conflict about what the EU as a polity is, how much power it should have in what fields, and where the political project of European integration should eventually lead. No longer the exclusive prerogative of elite executive actors, European politics are now shaped by a range of societal forces, including public opinion, mass media, political parties, interest groups and social movements. In this new context, grievances are articulated and reconstructed by political entrepreneurs in the public sphere. As such, mass media functions as the main locus where contestation takes place and where public opinion about Europe is formed (Statham \& Trenz 2013).

The origins of politicisation are sought in the increasing level, scope and inclusiveness of the EU itself (De Wilde \& Zürn 2012) - that is, exactly because the EU has become so influential, its powers and constitutional make-up become the focus of public attention. What is more, while European integration provokes societal contestation, the process of politicisation increasingly constrains future choices of integration. Whereas early theorists expected societal forces to be pro-integrationist and to demand a fully-fledged federal Europe (Schmitter 1969), recent research points to politicisation as a brake on integration, as citizens turn out to be more sceptical about the EU than elites (Hooghe \& Marks 2009).

Politicisation further highlights the importance of identity for EU politics (Checkel \& Katzenstein 2009; Risse 2010). The elusiveness of a European identity means many citizens feel decisions ought to be made at the national level, rather than in Brussels, to reflect the will and collective freedom of their national community. In the process of the unfinished constitutionalisation of the EU, the debate on the impact of politicisation includes the normative dimension of how desirable popular contestation is and whether it should be promoted or avoided (Føllesdal \& Hix 2006; Hix \& Bartolini 2006; Moravcsik 2006; Zürn 2006). Critics point especially to the different understandings and narratives that exist between Member States about the purpose, meaning and finality of European integration (Diez Medrano 2003) as well as the persistent gap between elites and citizens, with the latter being much less enthusiastic about the European project (Binnema \& Crum 2007; Ross 2008; Wessels 1995). Both point to a degree of fragmentation of audiences, with divisions between elite and mass audiences and between audiences of different nationality. 
Such fragmentation of audiences endangers the legitimation of the polity as it becomes difficult to design the EU in such a way as to command acceptance from everyone, or even from a majority (Dahlgren 2009).

Although the normative potential of politicisation remains debated in academic circles, both advocates and opponents agree that politicisation could be beneficial as long as a basic common ground is reached about the nature of the EU polity and its founding community (Papadopoulos \& Magnette 2010). Such a common ground can only come into existence if there is a free and rational exchange of arguments in the public sphere, with equal access to the debate for all (Eder \& Kantner 2000; Habermas 1985). This brings us back to the question of whether politicisation functions to expose Europeans to a variety of views, thus connecting them to a singular debate, or whether it fragments audiences across Europe. It also brings us back to the question of whether the positions brought to the fore in the process of politicisation provide sufficient rationale about what could provide the building blocks for a legitimate European Union.

Public opinion research on European integration tends to centre on the data available through Eurobarometer surveys (e.g., Boomgaarden et al. 2011; Lubbers \& Scheepers 2005; McLaren 2007). Yet, Eurobarometer has been criticised for posing questions that are not related to the respondents' lifeworld perceptions and experiences (Eder 2011). Besides survey data, we also have extensive knowledge on the types and degrees of party positions on Europe (Kopecký \& Mudde 2002; Szczerbiak \& Taggart 2008a, 2008b). Yet, there is much less information on how and to what extent these party positions are communicated through the public sphere (but see Kriesi (2007) and Statham and Koopmans (2009)). What is more, studies of 'supply side' and 'demand side' of public opinion are challenged by the increasing saliency of Europe in the 'marketplace' of the public sphere, as brought about by politicisation (De Vreese 2007; Koopmans \& Statham 2010; Kriesi 2007; Statham \& Trenz 2013). Survey analysis and party position measurements should therefore be complemented by studies of Europe's public spheres, especially in light of complex demands on how the political project of European integration and the EU polity ought to be publicly justified (Morgan 2005) and the highly idiosyncratic shape of national discourses (Diez Medrano 2003).

To complement existing studies on public opinion based on survey data and offline mass media, we focus on the micro level of opinion formation in online media. Although discrepancies between public opinion as measured through surveys and public opinion as expressed in online media remain, there is no denying the opinion formation function of mass media both generally (Gamson \& Modigliani 1989) and concerning European integration specifically (De Vreese 2007). The focus shifts from non-articulated and isolated attitudes on European integration to targeted, publicly articulated and frequently justified statements as elements of the ongoing public discourse on the EU.

We draw upon Morgan (2005) to conceptualise three different dimensions of the EU that ought to be evaluated in order to provide a 'full' or complete evaluation of the legitimacy of the EU polity. Only such full evaluations provide sufficient information to argue for a transformation of the European Union. This is so, because

the goal of at least some eurosceptics to abolish the EU is no less far-reaching than the project of at least some European federalists to establish a 'superstate'. If the 
arguments of these federalists must meet strict justificatory standards, because their goals are so transformative, the arguments of eurosceptics must meet strict justificatory standards too (Morgan 2005: 31)

The composition of arguments and justifications should be organised in such a way that it shows (a) whether the principle of transnational integration is defendable (are we better off doing things together?), (b) whether the institutional arrangement fits (is there a justifiable institutional framework that guarantees the general compliance with the principle?) and (c) whether the project is ideationally or materially supported (are there shared goals that drive the process of future integration?). This leads to the following typology of sufficiently complete forms of EU polity evaluation.

A combination of positive evaluations of all three dimensions can be labeled 'affirmative European' while its exact opposite is 'anti-European' (see Table 1). In between we find 'Status quo' and 'eurocritical' arguments. Not falling neatly into this ordinal scale are 'alter-European' and 'pragmatic' arguments that combine the counter-intuitive combination of negative evaluations of the EU polity with positive evaluations of future integration (alter-Europeanism) or negative evaluations of the principle of integration combined with a resignation to accept the EU as it is (pragmatism). Any of these six types of EU polity contestation would meet the discursive criteria of providing a complete evaluation of EU legitimacy in terms of justifying the 'polity worth' of the EU in all the three dimensions identified above. Yet, the actual practice of debating Europe does not always meet this argumentative strength and a separate category of incomplete polity contestation - 'diffuse euroscepticism' - must be conceptualised to capture stand-alone negative evaluations of the institutional set-up or project of integration without specification of preferences regarding the other two dimensions. Drawing on the conceptualisation of different economies of worth - ideological constructs based in normative theories about the common good (Boltanski \& Thévenot 2006) - this variety of EU polity evaluations can be justified based on principles of democracy, necessity, economic prosperity, culture or safety.

We do not expect politicisation to generate consensus across Europe on one of these six forms of polity evaluation. Rather, the increased saliency of the EU polity in some parts of Europe's public spheres is theorised to resonate in other parts. Diffusion takes place through public monitoring or direct exchange of arguments about problems of common concern. As

Table 1. Typology of complete EU polity evaluations

\begin{tabular}{|c|c|c|c|c|c|}
\hline & & \multicolumn{4}{|c|}{ Principle of integration } \\
\hline & & \multicolumn{2}{|c|}{ Positive } & \multicolumn{2}{|c|}{ Negative } \\
\hline & & \multicolumn{4}{|c|}{ EU institutional set-up } \\
\hline & & Positive & Negative & Positive & Negative \\
\hline \multirow[t]{2}{*}{ Project of integration } & Positive & $\begin{array}{l}\text { Affirmative } \\
\text { European }\end{array}$ & Alter-European & - & - \\
\hline & Negative & Status quo & Eurocritical & Pragmatic & Anti-European \\
\hline
\end{tabular}

Source: De Wilde and Trenz (2012). 
dissensus draws media attention and crystalises opinion, patterns of conflict are replicated over time and space. Conflicts are also increasingly found to structure the European political space in terms of stable cleavages and group polarisation along ideological or identity lines (Kriesi et al. 2008). Such conflicts can have a social ordering function and as such integrate the formerly fragmented European political space (Trenz 2005: 71). Polarisation facilitates social orientation also in the sense of positioning different actors and their divergent preferences. The Europeanised public spheres proliferate not through the consonances of unified discourse and understanding, but through the resonances of diverging opinions and conflicts (Eder \& Trenz 2003). Polarisation of opinion is therefore a necessary component of politicisation (De Wilde 2011: 567). Differences of opinion are thus likely to reproduce themselves through the mass media and resonate within the European public space. If audiences and participants of different public spheres sufficiently overlap, conflicts about Europe are transmitted from one forum to the other leading to a (limited) Europeanisation of public spheres (Koopmans \& Erbe 2004). Such a situation would mean that fragmentation between elites and masses and between different Member States is avoided. To find out whether there is evidence of such a structuring effect on public opinion as a result of mediated conflicts about European integration is a main aim of this article.

We can expect conflicting visions to exist in three dimensions. First, there are differences of public opinion on European integration across Member States. There are more enthusiastic and more 'awkward' partners in the European project. Politicians and citizens in some of the founding Member States have long advocated a fully federal European Union while those in newer Member States tend to be more sceptical. Some Member States notably the United Kingdom - continue to debate whether they want to be a member of this project at all (Fuchs et al. 2009; Harmsen \& Spiering 2004). Second, a gap between citizens and political elites has been reported. Elites throughout Europe tend to support the integration project more than their constituencies do as evidenced during referendums, when vast majorities of elected politicians advocate closer integration while only small majorities or minorities of citizens agree with them (Aarts \& Van der Kolk 2006; Binnema $\&$ Crum 2007; Hobolt 2009). Third, there appears to be differences of understanding both within and across Member States about the underlying purposes of integration, ranging from safeguarding peace, to modernisation, to creating jobs and economic growth (Diez Medrano 2003; Harmsen \& Spiering 2004). Especially, supporters and opponents of European integration appear to use different benchmarks by which to evaluate EU performance (Helbling et al. 2010), hence not engaging each other directly. If politicisation brings about an equal diffusion of the different positions and justifications across different national publics and elite and mass publics, it links these audiences to a similar debate. In this way, politicisation can signify a process toward legitimation of the EU. If, however, audiences are exposed to a limited sub-set of positions and justifications only, such a legitimation potential of politicisation cannot be expected.

\section{Data and method}

To capture interactive public opinion formation regarding the EU polity, we target debates on the Internet in a comparative research design. ${ }^{1}$ Professional news websites and political 
blogs increasingly offer readers the opportunity to respond to published texts in comments, frequently giving rise to lively discussions online. Political intermediation through the so-called 'traditional media' (newspapers, television, radio) is found to be limited in many ways. It is inherently linear, highly selective and exclusive in the sense that citizens remain, with few exceptions, mere observers of the political game. In the case of the EU, the traditional media have also repeatedly been found to re-affirm the nation-state and the legitimacy of contextualised national politics (Trenz 2004). We argue that the online media offers an ideal environment for analysing contestation of the EU precisely because they allow us to systematically link political contestation and citizens' participation with public salience and media framing (cf. Michailidou and Trenz 2010).

In order to identify our sample population, we followed Schneider and Foot's definition of a web sphere as 'a hyperlinked set of dynamically defined digital resources that span multiple websites and are deemed relevant, or related, to a central theme or "object", (Schneider \& Foot 2004: 118). In such web spheres, one big event or chain of events (in our case, the EP elections of 2009) may trigger a series of inter-actor and inter-site activity online known as 'web storms' (Schneider \& Foot 2005: 162-163). Media coverage of the EP election campaign peaks in the three weeks before the election dates up until several days after the last elections (Schuck et al. 2011). Our monitoring period was thus limited from 18 May 2009 until 10 June 2009.

The sample comprises only the most popular web spaces per country and at transEuropean level. In total, we have included 36 professional journalism websites and 24 independent blogs of national scope, while at European/transnational level we have included one professional journalism website and two blogs. ${ }^{2}$ To supplement our data from the transnational news websites, which attract a niche, arguably elite, audience, with data from more popular, less elitist online forums, we also included two Twitter threads with EU election-related hash tags. For the same reason, we decided to include two Facebook groups and one 'fan page' focused on the EU elections as sources of online debate, even though they do not fall within our definition of the online news media sphere. The selected Facebook sources came up during the analysis of in-linking and out-linking patterns of the trans-European news websites. The EP fan page (not to be confused with the official EP Facebook page) counted over 55,000 members at the time of the sampling (see Online Appendix for details), while the two groups were set up specifically for the 2009 elections and counted 5,953 and 2,719 members, respectively.

It is in the application of a rigorous quantitative content analysis to cross-country Internet data that our methodology is highly innovative. Relatively few studies have so far targeted news websites and political blogs in multiple countries in such a manner (but see Jankowski and Van Selm (2008) and Strandberg (2008)). Researchers have thus far deployed a multitude of deliberative communication models devised to assess online political debates (Surel 2000; Trenz 2009). However, the abstract nature of the subject of measurement (deliberation) and the complexity of the models reduce both the comparability of the results and the reliability of the measurements. This is primarily because these models allow for high levels of inter-/intra-coder bias and arbitrary interpretations of the participants' intentions. Instead, we focus on the content found in selected threads of specifically chosen websites, thus conducting a form of discourse analysis of the web at micro level (Schneider \& Foot 2004, 2005). To capture individual contributions to EU polity 
contestation, we operationalised the unit of analysis as a 'message', which is defined as one or more evaluations on European integration made by a single (collective) actor in a single time and space. When coding a message, we identify first who transmits it (EU, foreign and/or domestic actors, state and non-state actors, citizens, journalists and/or politicians). We then record the kinds of evaluations a message contains of the EU polity. This entails the coding of message along one, two or all three of the following dimensions: principle of European integration, institutional set-up of the EU and project of integration. An evaluation can be positive or negative and, in the latter two dimensions, it can further address the level, scope or inclusiveness of integration (see the Online Appendix). Finally, we code the justification given, if any, by the actor for the presented evaluations of EU legitimacy.

An example of a message containing multiple evaluations is 'European integration is undemocratic and the EU should therefore be abolished'. This example contains a negative evaluation of the principle of integration and of the current institutional set-up of the EU. We can safely classify this statement as 'anti-European' despite missing information on the future project or trajectory of integration. Yet, apart from the six complete types of EU polity evaluation identified above, our analysis also points out a number of truncated evaluations, which remain under-specified. Statements like 'the Common Market dismantles the welfare state' or 'EU enlargement is a threat to security' clearly express dissatisfaction in some form with the EU, yet do not specify the full extent of this dissatisfaction nor possible remedies. We do not know whether the maker of the first example wants to abolish the Common Market or modify it in such a way as to rescue the welfare state. We also do not know whether the maker of the second example appreciates the EU without enlargement or does not appreciate the EU at all. Such truncated evaluations thus do not meet the criteria of a sufficient argument justifying a transformation of the EU polity and therefore fall into a seventh group of polity evaluations, which we label 'diffuse euroscepticism'.

To operationalise justification, we draw upon the classification of justifications as economies of worth developed by Boltanski and Thévenot (2006). Accordingly, the legitimacy of the EU can be defended on the basis of claims that (1) European integration increases democracy; (2) European integration serves the purpose of preserving a shared cultural heritage and Europe-wide shared values; (3) European integration is necessary to cope with modern policy problems or in light of previous commitments; (4) European integration increases prosperity through stimulating economic growth and general welfare; or (5) European integration is regarded as protecting Europe from internal and/or external threats of various nature. On the same principles, the legitimacy of the EU can be denounced.

We therefore assume that the register of justifications of European integration on which situated actors can draw is limited and that critical practices follow particular scripts and guidelines, which are de-contextualised and generalised as part of the cultural repertoire of modern societies (Wagner 2008). Yet, by including the category 'other' it was acknowledged that particular justifications could fall outside of this matrix. Following this matrix, justifications were coded as the explicit reasons given by the actor of the message for his or her evaluation. The key factor here is not the action of the maker of an argument, but the message that reaches the audience. Thus, if a message transmits a common value based on which the contribution inclines the audience to consider European integration and/or the EU in connection to the evaluation presented, we would code this as a justification of worth. 
Linked to this, we have to stress that our classification of EU polity 'messages' according to justification of worth does not aim to assess the deliberative quality of these messages. ${ }^{3}$ In the tradition of an empirical sociology of critique as formulated by Boltanski and Thévenot (2006), we rather want to map out the type of views put forward by diverse actors in the online public sphere regarding the EU polity. We are thus not interested in individual attitudes as, for instance, measured through questionnaires but in the critical discourse that unfolds through the exchange of arguments and justifications and that is uttered and amplified through the media. The mediated contestation of arguments about the scope and viability of European integration stands in this sense for a dynamic formation of public opinion in which the 'polity worth' of the EU is given meaning and classified.

We used Krippendorff's alpha to measure inter-coder reliability before, during and at the end of the coding period (eight coders were involved). For the test, a sub sample of threads from United Kingdom-based websites was used, as all coders had sufficient grasp of the English language. All variables had a score of 0.7 and higher, with the exception of the EU polity evaluation, where the score was 0.628 . Although this is slightly below the usually recommended minimum measurement of alpha (0.667), we have accepted it as valid and reliable score as the actual coding practice was continuously discussed within the group, providing for higher reliability than the formal test would lead to assume.

\section{Findings}

Positive contributions to EU polity contestation in one or several dimensions - affirmative European, status quo, alter-European, eurocritical and pragmatic contributions - are only found in about a third of all messages. Yet, it is the openly anti-European contributions to discourse - those categorically opposing the principle of integration and possibly the current institutional set-up and/or project - that remain rather marginal (6.7 per cent of all evaluations). Clearly, the incomplete category of diffuse eurosceptic statements is the most numerous, accounting for over half of all statements (see Table 2). This reflects the strongly negative tone in the debates.

Table 2. Relative frequencies of different forms of EU polity evaluation

\begin{tabular}{llr}
\hline & Form of polity evaluation & Percentage \\
\hline Complete & Affirmative European & 15.5 \\
& Status quo & 10.4 \\
& Alter-European & 4.6 \\
& Eurocritical & 5.4 \\
& Pragmatic & 0.1 \\
Incomplete & Anti-European & 6.7 \\
Total & Diffuse eurosceptic & 57.3 \\
$\mathrm{~N}$ & & 100.0 \\
\end{tabular}


Aside from their unmistakably negative connotation, it is hard to establish in what sense or direction the EU polity is contested by diffuse eurosceptic evaluations - that is, the missing information resulting from addressing only one or two dimensions of integration makes it impossible to determine into which of the six 'full' categories in our typology the evaluation would fall. There is thus an inbuilt ambiguity in the negative evaluations of EU legitimacy. Such diffuse euroscepticism could load onto either status quo ('no more further steps'), alter-European ('a different Europe') or eurocritical ('not this Europe') type of arguments. This would assume some form of support for cooperation among European nation-states despite the criticism voiced. Alternatively, eurosceptic contributions could reflect anti-European ('no Europe at all') arguments, opposing any form of cooperation. The problem is that the makers of those arguments simply do not provide sufficient information about their preferences to allocate their contributions to one of these four types.

The conclusion is that only a minority of communicated contributions in the public sphere come close to the normative template of a 'complete' argument about transforming the EU polity in terms of principle, institutional design and project. The majority of contributions falls short of clarifying the context conditions for the validity of their arguments, and they do not point at possible solutions. In other words, EU polity contestation online predominantly spreads an under-specified critique of the EU and European integration. We are witnessing relatively unclear expressions of discontent, rather than precisely formulated and substantiated evaluations of the EU polity. In other words, we only get a little information about the kind of European polity that would be supported or which characteristics of the EU, exactly, are opposed by the participants in the Internet.

\section{Intensity of debate and convergence on euroscepticism}

These total relative frequencies of different kinds of EU polity contestation provide a general overview of the tone of the debate online, but they do not answer the question whether politicisation functions to synchronise debates across Europe's public spheres. Figure 1 shows the intensity of debate on the EU polity in terms of the average amount of evaluations per online article. Clearly, at the time of the 2009 EP election campaigns, the EU polity was most contested in the United Kingdom with an average of a little over five evaluations per article. We find the least intense debate in Greece, with hardly any evaluations per article. ${ }^{4}$

On the one hand, these differences in the intensity of debate reflect the controversy of the EU in the country in question. Countries that are known to be 'awkward partners' in the European project - particularly the United Kingdom - feature much more intense EU polity contestation than the ones where participation in European integration has long remained unquestioned. Also, we see a residual of treaty ratification referendums in the Netherlands and France where extensive debates about the legitimacy of the EU held in 2005 are to some extent replicated in the 2009 European election campaigns (cf. De Wilde et al. 2013). On the other hand, the intensity of debate reflects the digital divide within Europe in terms of the spread of Internet access and the extent to which Web 2.0 features of interactive debate have penetrated society. Web 2.0 features were less diffused in Eastern and Southern Europe at the time of analysis. 


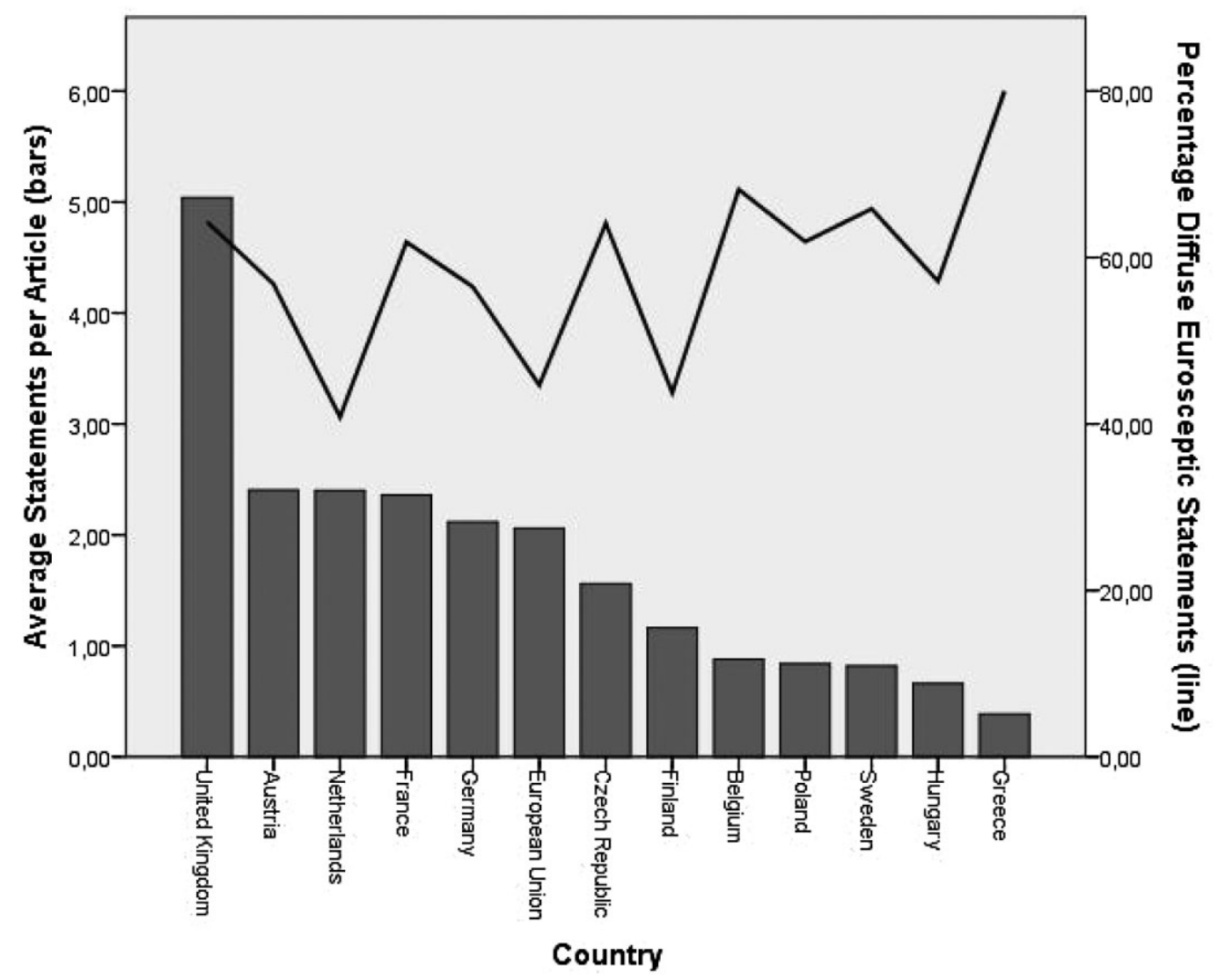

Figure 1. Intensity of debate and diffuse euroscepticism.

Most interestingly, and against some of the predictions found in the literature (e.g., Moravcsik 2006), more politicisation in terms of intensity of debate does not mean more euroscepticism. Rather, politicisation amplifies the diversity of arguments and justifications of EU polity worth. If anything, as Figure 1 shows, the debate about Europe becomes more specified as it becomes more intense as the percentage of diffuse eurosceptic evaluations tends to be slightly lower in countries with a higher average of EU polity evaluations per online article.

\section{A gap between citizens and elites?}

The next step in our analysis is to determine to what extent these online debates, diffuse eurosceptic and varied in intensity as they are, reflect the alleged citizen-elite divide. Interactive websites are ideal for studying this as citizens voluntarily leave comments on news stories that often feature the arguments by political elites. Not only do we capture similar units of analysis in terms of arguments, we capture them in direct communicative confrontation with each other. On the one hand, we would expect elite voice to become 
Table 3. EU polity evaluations by party actors and citizens (\%)

\begin{tabular}{lcr}
\hline & \multicolumn{2}{c}{ Actor } \\
\cline { 2 - 3 } Polity contestation & Party actor & Citizens \\
\hline Affirmative European & 27.3 & 8.5 \\
Status quo & 7.8 & 10.6 \\
Alter-European & 5.5 & 4.1 \\
Eurocritical & 5.5 & 5.5 \\
Pragmatic & 0.0 & 0.1 \\
Anti-European & 6.5 & 7.3 \\
Eurosceptic & 47.4 & 63.9 \\
Total & 100.0 & 100.0 \\
$\mathrm{~N}$ & 308 & 714 \\
\hline
\end{tabular}

dominant on professional news sites as governments and mainstream political parties retain a strong position as main communicators about Europe. Citizens, on the other hand, could be expected to dismiss the elite consensus on European integration. The predominantly pro-European voice of elites, amplified by the media, could further create eurosceptic counter-reactions (De Wilde \& Trenz 2012). Euroscepticism could thus spread independently of the mobilisation by political parties as a negative response of the audience to the predominance of pro-European elite discourse. For these reasons, we are interested in establishing whether political elites evaluate European integration and the EU differently in online EP election campaigns than citizens do (see Table 3).

Our aggregated media data of mainstream professional news sites and political blogs confirms the existence of a citizen-elite divide in media discourse on Europe. Political party actors are clearly more prone to making pro-European arguments than are citizens and contribute fewer diffuse eurosceptic arguments, as shown in Table 4. There is a clear association between the actor and the type of evaluation advanced $\left(\chi^{2}(6, N=\right.$ $1,022)=66.530, p<0.000$, Cramer's $V=0.255$ ). Still, it could be argued that these discursive differences during the $2009 \mathrm{EP}$ elections campaign are less pronounced than those reported between national parliamentarians and voters during many of the referendums on treaty change. The gap between citizens and elites may thus be decreasing or it may not be as pronounced on the web as it is 'offline'. There is thus partial evidence that expressions of diffuse euroscepticism are reactions to pro-European elites. It is not necessarily made visible through the inputs of eurosceptic parties but are, nevertheless, strong in citizens' comments.

\section{Justifying EU polity contestation}

In the following, we distinguish how citizens and political elites evaluate the EU polity differently by reference to the five broad categories of justifications of worth. We find a substantial association between actors and justifications $\left(\chi^{2}(6, N=1,023)=84.111\right.$, $p<0.000$, Cramer's $V=0.287)$. Generally, party actors justify their legitimacy evaluations 
Table 4. Justifications by actor type (\%)

\begin{tabular}{lcr}
\hline & \multicolumn{2}{c}{ Actor } \\
\cline { 2 - 3 } Justification of worth & Party actor & Citizens \\
\hline Democracy & 20.1 & 43.4 \\
Culture & 9.7 & 4.8 \\
Necessity & 6.5 & 12.5 \\
Economic prosperity & 6.8 & 8.1 \\
Safety & 7.8 & 4.5 \\
Other & 1.0 & 0.3 \\
Not applicable & 48.1 & 26.5 \\
Total & 100.0 & 100.0 \\
N & 308 & 714 \\
\hline
\end{tabular}

less often than citizens. Citizens are also much more likely to evaluate the EU or European integration based on a concern with democracy than party actors. The question is whether this type of evaluation is mainly evoked in a legitimating (affirmative European) or in a delegitimating (eurocritical or anti-European) context.

Table 5 shows first, how certain justifications in the context of EP election debates particularly those concerning democracy and necessity - are more often invoked than others, irrespective of the type of argument made. ${ }^{5}$ There is a clear tendency in all countries to criticise the EU in an electoral contest on the basis of alleged democracy deficits rather than to support EU legitimacy by reference to democratic credentials. Actors making supportive evaluations, in turn, tend to base their justifications on a 'functional' argumentation grounding EU legitimacy in the necessity of its regulative framework or the safety provided by it. Two other justifications of worth - culture and economic prosperity - are invoked by both those positively and negatively evaluating the EU.

\section{Discussion}

Our findings point to the high visibility of online EU polity contestation as an element of EP election campaigning that is partly detached from partisan contestation. Our discussion of polity contestation in the context of the 2009 EP election campaigns supports the notion that politicisation functions to diffuse both positive and negative evaluations as well as a range of justifications of the EU across different public spheres, hence featuring more intensity of debate and polarisation of opinion without fragmenting the audiences. Discursive efforts to establish EU legitimacy in terms of principle, institutional set-up and project evoke transformative counter arguments and vice versa.

We find that EU polity contestation during the 2009 EP election campaigns predominantly concerns the current institutional set-up of the EU. There are fewer evaluations concerning the future project of integration and even less evaluations of the principle of integration. This is reflected in a dominance of diffuse eurosceptic contributions to the 


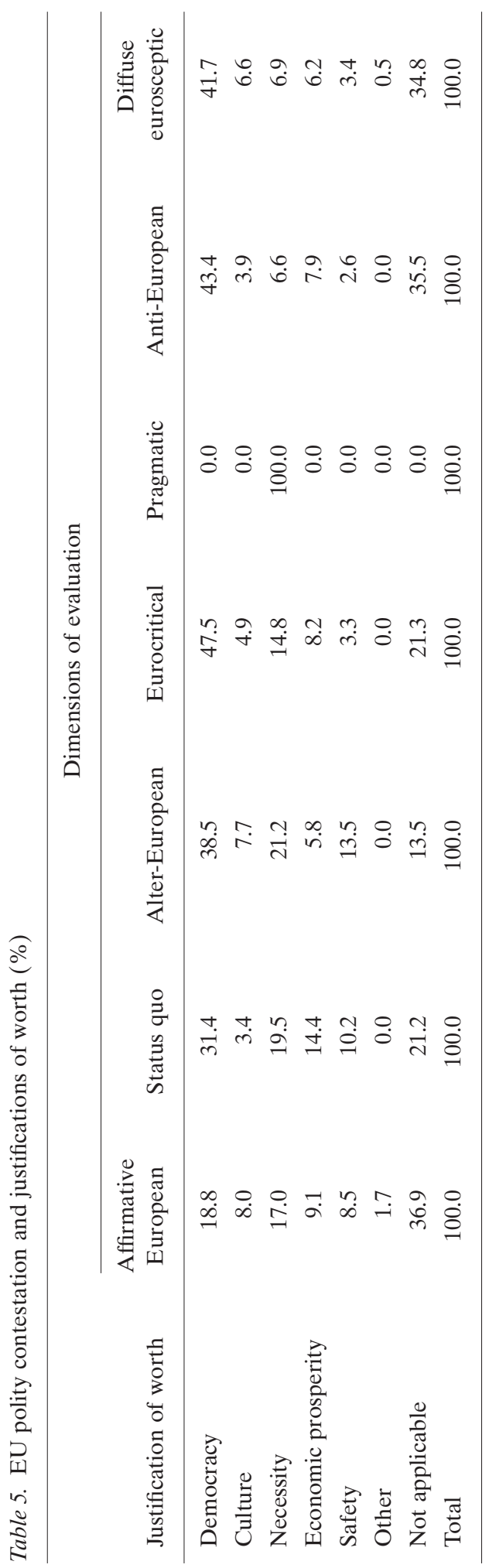


debate, as opposed to more complete EU polity evaluations. The lack of contestation on the principle of integration may point to general acceptance among European political elites and citizens that some form of collaboration is warranted among European nation-states, given their economic interdependencies and historical relations. Future research should investigate whether this motivation indeed lies behind a lack of salience of this dimension of EU polity evaluation. Furthermore, after the anticipated completion of the ratification of the Treaty of Lisbon, grand-scale future plans for further integration may have (temporarily) disappeared from the public agenda. The strong criticism of the current institutional set-up of the EU, in combination with a lack of contestation on the project of integration, implies a stalemate in which polity opposition frequently remains detached from a discussion on possible reform. Whereas the principle of integration is largely evaluated positively, the current set-up of the EU is largely evaluated negatively. Evaluations on the project differ and views on future integration diverge among countries.

Our online discourse data supports the presence of a citizens-elite divide, which is regularly considered as one of the central vectors structuring public opinion on European integration. Citizens express themselves clearly as more critical of the EU than party actors, with party actors making more affirmative European arguments and citizens making more diffuse eurosceptic arguments. We also find evidence of the divide between party actors and citizens in terms of justification, with citizens expressing a clear concern with democracy and partisan actors being only partly responsive to these concerns and, in general terms, justifying their arguments less frequently. Concerns with democracy expressed mainly by citizens are furthermore mostly evoked in a negative (delegitimising) context, while justifications relating to necessity and safety, expressed predominantly by party actors, are used to support the EU. In an electoral contest, such a citizens-elite divide can be interpreted as a gap in representation. Although these differences between citizens and elites are observed in our study, the alleged divide appears less pronounced than often described in the literature. Further research should investigate whether there is offline evidence of a persistent, yet reduced, citizen-elite divide too.

Interestingly, the content of evaluations does not vary substantially among the countries involved in our study. Rather, what differs is the intensity of debate as measured in the amount of polity evaluations. In the United Kingdom, Austria and the Netherlands, where European integration is more salient and public opinion is more critical, we find a higher amount of polity evaluations. In contrast, Greece and Hungary, where European integration was relatively uncontroversial up until the outbreak of the euro crisis, feature few evaluations. This draws our attention to the logics of polity opposition (Mair 2005, 2007). Media debates on the EU as a polity are predominantly driven by those critical or dissatisfied with the political status quo, as in political debates in general (Gamson 1968: 48). In other words, there is a bias in online media that favours opposition over affirmative voice. Reasons for this are manifold. Negative news is often found to have a higher news value and journalists as the gatekeepers of media discourse tend to selectively amplify discontent with European integration. In addition, actors supportive of European integration and content with the status quo have fewer incentives to voice their opinions online than do disgruntled actors. Especially citizens, who mainly account for the high salience of diffuse eurosceptic evaluations in the media, display a strong bias towards expressions of dissatisfaction with the EU and European integration. In this sense, we can conclude that online media tends 
to amplify diffuse euroscepticism while pro-European arguments are less likely to become salient on the Internet.

All this constitutes a major challenge to those who would like to transform the EU while taking public opinion about the EU polity seriously. Clearly, the dominance of diffuse euroscepticism and citizens' explicit concern with the democratic credentials of the Union supports those who wish to proceed with a transformative agenda. Yet, while this study provides evidence of a convergence across Europe in terms of prominent diffuse euroscepticism and replication of conflicts over the principle of integration, the institutional set-up of the EU and the future project of integration, little information is provided by the participants of online debates about what would alleviate their discontent. To return to our initial question, we thus find little evidence of the potential for legitimation through politicisation in online public spheres. Although there is no shortage of opinions about the EU in the online media spheres we have examined, the predominant opinion (diffuse euroscepticism) is too vague to allow implementation of reforms. There appears substantial consensus that the current EU set-up is not satisfactory, but the legitimate way forward is not voiced publicly in a clear enough manner.

\section{Acknowledgements}

The research for this article was conducted as part of RECON (Reconstituting Democracy in Europe) - a European Commission funded project under FP6, directed by Erik Oddvar Eriksen and John Erik Fossum at ARENA, Center for European Studies, University of Oslo. We would like to thank all the coders involved in data collection and the participants at the project workshop in Krakow, at the Jagiellonian University, May 2010. Earlier versions of this article were presented at ARENA, April 2010; the ECPR General Conference in Reykjavik, August 2010; and the DVPW IB Sektionstagung in Munich, November 2010. We would like to thank all participants at those events. Special thanks go to Matthias Ecker-Ehrhardt, Christopher Lord and Jürgen Neyer, the editors at EJPR and the two anonymous reviewers for elaborate comments. All remaining errors are our own.

\section{Supporting Information}

Additional Supporting Information may be found in the online version of this article at the publisher's web-site:

Online Appendix

Appendix Table 1: Total amount of collected articles covering the 2009 European Parliament elections, per country (Data source: the authors)

Appendix Table 2: Results of formal inter-coder reliability test

\section{Notes}

1. Although not all citizens follow political debates online and few actively participate in them, the Internet as a medium for political communication is of growing importance. Still, we should be careful not to 
assume that citizens participating in online political debates form a representative sample of the population. They tend to be young, male and highly educated in comparison to the population at large (Albrecht 2006; Norris 2001).

2. See the Online Appendix for more detailed information about the data and sampling.

3. Whether EU public contestation is comprised largely of justified or non-justified statements is certainly relevant if we are to assess the deliberative quality of discussions on EU issues. Such an endeavour is, however, outside the scope of this article.

4. Note that our data stems from before the outbreak of the Greek sovereign debt crisis; political debate about the EU polity in Greece may well have increased since then.

5. It is not surprising to find frequent justifications concerning democracy during EP election campaigns since this is a key democratic moment. However, the prominence of 'democracy' as economy of worth in the debate and its more frequent usage by those making more critical evaluations of the EU remain.

\section{References}

Aarts, K. \& Van der Kolk, H. (2006). Understanding the Dutch 'no': The euro, the east and the elite. PS: Political Science and Politics 39: 243-246.

Albrecht, S. (2006). Whose voice is heard in online deliberation? A study of participation and representation in political debates on the Internet. Information, Communication and Society 9: 62-82.

Binnema, H. \& Crum, B.J.J. (2007). Resistance to Europe as a carrier of mass-elite incongruence: The case of the Netherlands. In J. Lacroix \& R. Coman (eds), Les Résistance à l'Europe: Cultures Nationales, Ideologies et Stratégies d'Acteurs. Bruxelles: Université de Bruxelles.

Boltanski, L. \& Thévenot, L. (2006). On Justification: Economies of Worth. Princeton, NJ: Princeton University Press.

Boomgaarden, H.G. et al. (2011). Mapping EU attitudes: Conceptual and empirical dimensions of euroscepticism and EU support. European Union Politics 12: 241-266.

Boomgaarden, H.G. et al. (2013). Across time and space: Explaining variation in news coverage of the European Union. European Journal of Political Research 52: 608-629.

Checkel, J.T. \& Katzenstein, P.J. (2009). The politicization of European identity. In European Identity. Cambridge: Cambridge University Press.

Dahlgren, P. (2009). Media and political engagement: Citizens, communication and democracy. Cambridge: Cambridge University Press.

De Vreese, C.H. (2007). A spiral of euroscepticism: The media's fault? Acta Politica 42: 271-286.

De Wilde, P. (2011). No polity for old politics? A framework for analyzing politicization of European integration. Journal of European Integration 33: 559-575.

De Wilde, P. \& Trenz, H.-J. (2012). Denouncing European integration: Euroscepticism as polity contestation. European Journal of Social Theory 15: 537-554.

De Wilde, P. \& Zürn, M. (2012). Can the politicization of European integration be reversed? Journal of Common Market Studies 50: 137-153.

De Wilde, P., Michailidou, A. \& Trenz, H.-J. (2013). Contesting Europe: Exploring euroscepticism in online media coverage. Colchester: ECPR Press.

Diez Medrano, J. (2003). Framing Europe: Attitudes to European integration in Germany, Spain and the United Kingdom. Princeton, NJ: Princeton University Press.

Eder, K. (2011). Europe as a narrative network: Taking serious the social embeddedness of identity constructions. In S. Lucarelli, F. Cerutti \& V.A. Schmidt (eds), Debating political identity and legitimacy in the European Union: Interdisciplinary views. London: Routledge.

Eder, K. \& Kantner, C. (2000). Transnationale Resonanzstrukturen in Europa: Eine Kritik der Rede vom Öffentlichkeitsdefizit. In M. Bach (ed.), Die Europäisierung nationaler Gesellschaften. Wiesbaden: Westdeutscher Verlag.

Eder, K. \& Trenz, H.-J. (2003). The making of a European public sphere: The case of justice and home affairs. In B. Kohler-Koch (ed.), Linking EU and national governance. Oxford: Oxford University Press. 
Føllesdal, A. \& Hix, S. (2006). Why there is a democratic deficit in the EU: A response to Majone and Moravcsik. Journal of Common Market Studies 44: 533-562.

Fuchs, D., Magni-Berton, R. \& Roger, A. (eds) (2009). Euroscepticism: Images of Europe among mass publics and political elites. Opladen: Barbara Budrich.

Gamson, W.A. (1968). Power and discontent. Homewood, IL: Dorsey Press.

Gamson, W.A. \& Modigliani, A. (1989). Media discourse and public opinion on nuclear power: A constructionist approach. American Journal of Sociology 95: 1-37.

Habermas, J. (1985). The theory of communicative action: Reason and the rationalization of society. Boston, MA: Beacon Press.

Harmsen, R. \& Spiering, M. (eds) (2004). Euroscepticism: Party politics, national identity and european integration. Amsterdam: Rodopi.

Helbling, M., Hoeglinger, D. \& Wueest, B. (2010). How political parties frame European integration. European Journal of Political Research 49: 496-521.

Hix, S. \& Bartolini, S. (2006). Politics: The right or the wrong sort of medicine for the EU? Policy Paper 19. Brussels: Notre Europe. Available online at: www.notre-europe.eu/uploads/tx_publication/ Policypaper19-en.pdf

Hobolt, S.B. (2009). Europe in question: Referendums on European integration. Oxford: Oxford University Press.

Hooghe, L. \& Marks, G. (2009). A postfunctionalist theory of European integration: From permissive consensus to constraining dissensus. British Journal of Political Science 39: 1-23.

Jankowski, N.W. \& Van Selm, M. (2008). Internet-based political communication research: Illustrations, challenges and innovations. Javnost - The Public 15: 5-16.

Koopmans, R. \& Erbe, J. (2004). Towards a European public sphere? Vertical and horizontal dimensions of Europeanized political communication. Innovation 17: 97-118.

Koopmans, R. \& Statham, P. (eds) (2010). The making of a European public sphere: Media discourse and political contention. Cambridge: Cambridge University Press.

Kopecký, P. \& Mudde, C. (2002). The two sides of euroscepticism: Party positions on European integration in East Central Europe. European Union Politics 3: 297-326.

Kriesi, H. (2007). The role of European integration in national election campaigns. European Union Politics 8: 83-108.

Kriesi, H. et al. (2008). West European politics in the age of globalization. Cambridge: Cambridge University Press.

Lubbers, M. \& Scheepers, P. (2005). Political versus instrumental euroscepticism. European Union Politics 6: $223-242$.

Mair, P. (2005). Popular democracy and the European Union polity. European Governance Papers C-05-03. Available online at: www.ihs.ac.at/publications/lib/ep3.pdf

Mair, P. (2007). Political opposition and the European Union. Government and Opposition 42: 1-17.

McLaren, L. (2007). Explaining mass-level euroscepticism: Identity, interests and institutional distrust. Acta Politica 42: 233-251.

Michailidou, A. \& Trenz, H.-J. (2010). Mediati(zi)ng EU politics: Online news coverage of the 2009 European Parliamentary elections. Communications 35: 327-346.

Moravcsik, A. (2006). What can we learn from the collapse of the European constitutional project? Politische Vierteljahresschrift 47: 219-241.

Morgan, G. (2005). The idea of a European superstate: Public justification and European integration. Princeton, NJ: Princeton University Press.

Norris, P. (2001). Digital divide: Civic engagement, information poverty and the Internet in digital societies. Cambridge: Cambridge University Press.

Papadopoulos, Y. \& Magnette, P. (2010). On the politicisation of the European Union: Lessons from consociational national politics. West European Politics 33: 711-729.

Rauh, C. (2012). Politicisation, Issue Salience and Consumer Policies of the European Commission. Doctoral dissertation. Berlin: Free University Berlin.

Rauh, C. \& Zürn, M. (2013). The Politicization of the EU in Times of Crisis: Implications for Institutional Design. Paper presented at the CES 20th International Conference of Europeanists, Amsterdam. 
Risse, T. (2010). A community of Europeans? Transnational identities and public spheres. Ithaca, NY: Cornell University Press.

Ross, G. (2008). What do 'Europeans' think? Analyses of the European Union's current crisis by European elites. Journal of Common Market Studies 46: 389-412.

Schmitter, P.C. (1969). Three neo-functional hypotheses about international integration. International Organization 23: 161-166.

Schneider, S.M. \& Foot, K.A. (2004). The web as an object of study. New Media \& Society 6:114-122.

Schneider, S.M. \& Foot, K.A. (2005). Web sphere analysis: An approach to studying online action. In C. Hine (ed.), Virtual methods: Issues in social research on the Internet. Oxford: Berg.

Schuck, A.R.T. et al. (2011). Party contestation and Europe on the news agenda: The 2009 European Parliament elections. Electoral Studies 30: 41-52.

Statham, P. \& Koopmans, R. (2009). Political party contestation over Europe in the mass media: Who criticizes Europe, how and why? European Political Science Review 1: 435-463.

Statham, P. \& Trenz, H.-J. (2013). The politicization of Europe: Contesting the constitution in the mass media. Abingdon: Routledge.

Strandberg, K. (2008). Public deliberation goes online? Javnost - The Public 15: 71-90.

Surel, Y. (2000). The role of cognitive and normative frames in policy-making. Journal of European Public Policy 7: 495-512.

Szczerbiak, A. \& Taggart, P. (eds) (2008a). Opposing Europe? The comparative party politics of euroscepticism. Vol. 1: Case studies and country surveys. Oxford: Oxford University Press.

Szczerbiak, A. \& Taggart, P. (eds) (2008b). Opposing Europe? The comparative party politics of euroscepticism. Vol. 2: Comparative and theoretical perspectives. Oxford: Oxford University Press.

Trenz, H.-J. (2004). Media coverage on European governance: Exploring the European public sphere in national quality newspapers. European Journal of Communication 19: 291-313.

Trenz, H.-J. (2005). Europa in den Medien. Die europäische Integration im Spiegel nationaler Öffentlichkeit. Frankfurt: Campus Verlag.

Trenz, H.-J. (2009). Digital media and the return of the representative public sphere. Javnost - The Public 16: 33-46.

Wagner, P. (2008). Modernity as experience and interpretation: A new sociology of modernity. Cambridge: Polity Press.

Wessels, B. (1995). Evaluations of the EC: Élite or mass-driven? In O. Niedermayer \& R. Sinnott (eds), Public opinion and internationalized governance. New York: Oxford University Press.

Winzen, T. (2012). National parliamentary control of European Union affairs: A cross-national and longitudinal comparison. West European Politics 35: 657-672.

Zürn, M. (2006). Zur Politisierung der Europäischen Union. Politische Vierteljahresschrift 47: 242-251.

Address for correspondence: Pieter de Wilde, WZB Berlin Social Science Centre, Reichpietschufer 50,10785 Berlin, Germany. E-mail: pieter.dewilde@wzb.eu 